\title{
Carmen Conde, desde su Edén
}

\author{
Pascual García \\ Universidad de Murcia
}

Vuelve a mostrar su excelencia investigadora y su sabiduría lectora el catedrático de literatura jubilado de la Universidad de Murcia, Francisco Javier Díez de Revenga, en esta nueva obra ${ }^{1}$ de una gran profundidad filológica. En ella aborda la labor poética de Carmen Conde, cartagenera, personaje indiscutible de las letras nacionales, primera académica, mujer controvertida y libérrima, que elaboró durante su vida excelentes poemarios, a los que Díez de Revenga va dando cumplida y pormenorizada lectura crítica: Mujer sin edén (al que se alude en este título), Ansia de la gracia, La noche oscura del tiempo, Pasión del verbo, En un mundo de fugitivos, Derribado arcángel, Los poemas del Mar Menor, En la tierra de nadie o Cráter, por poner algunos de los muchos ejemplos de una poeta prolífica, que en ningún momento descuida la calidad ni la aventura de la vida, protagonista como es de una era dorada de la literatura y del arte español.

Díez de Revenga examina a conciencia y con rigor la mayor parte de estos libros, pero no descuida la biografía de la autora, su relación epistolar y literaria con figuras tan emblemáticas como Juan Ramón Jiménez o Gabriel Miró: «Hay que valorar una vez más y manifestar nuestro respeto y nuestro entusiasmo por la fuerza de voluntad de una mujer que, desde muy joven, luchó por afirmar sus capacidades intelectuales, sobreviviendo a las adversidades de la incomprensión, en muchas ocasiones por el mero hecho de ser mujer».

El autor de este importante y decisivo recorrido por la poesía de Carmen Conde no se olvida de reivindicar el ejemplo de una mujer que luchaba en un tiempo y en un país dominado por hombres y que, a pesar de todo, supo y pudo estar a la altura de sus colegas y recibió grandes elogios de los patriarcas de las letras hispanas, que en aquellos años y todavía hoy constituyen un referente del arte de la palabra en el mundo.

${ }_{1}$ Francisco Javier Díez de Revenga, Carmen Conde, desde su Edén, Murcia, Real Academia Alfonso X el Sabio, 2020, 333 págs. 
El profesor murciano establece a lo largo de las páginas bien nutridas de este tomo fundamental para la comprensión definitiva de la palabra creadora de Carmen Conde una visión acertada y bien argumentada de las capacidades poéticas, de los hallazgos expresivos y del valor lírico de la obra de la poeta cartagenera: «Forja la autora también un estilo muy personal, basado desde el comienzo en un particular dominio de la metáfora, acorde con las corrientes estéticas que dominaron la poesía joven de los años finales de la década de los veinte».

Pero también se aborda aquí su relación con la obra de Miguel Hernández y Rubén Darío y con su amiga de toda la vida, Amanda Junquera, a la que se refiere de una manera especial en uno de los capítulos más originales de este libro, referido al género de las dedicatorias, Dedicatorias a Amanda: un género literario que no suele recibir atención de los estudiosos, dado su carácter circunstancial, y en la mayor parte de los casos, formulario, de cortesía, de escaso interés literario.

Como suele pasar en todos los libros de Javier Díez de Revenga, también en este encontrará el lector una dosis bien fundada de conocimiento, sabiduría e investigación rigurosa junto a las huellas inmarcesibles de un gusto exquisito que tal vez nos obligue a la lectura de los libros que se citan en estas páginas dedicadas a la mujer escritora por excelencia de las letras españolas. 